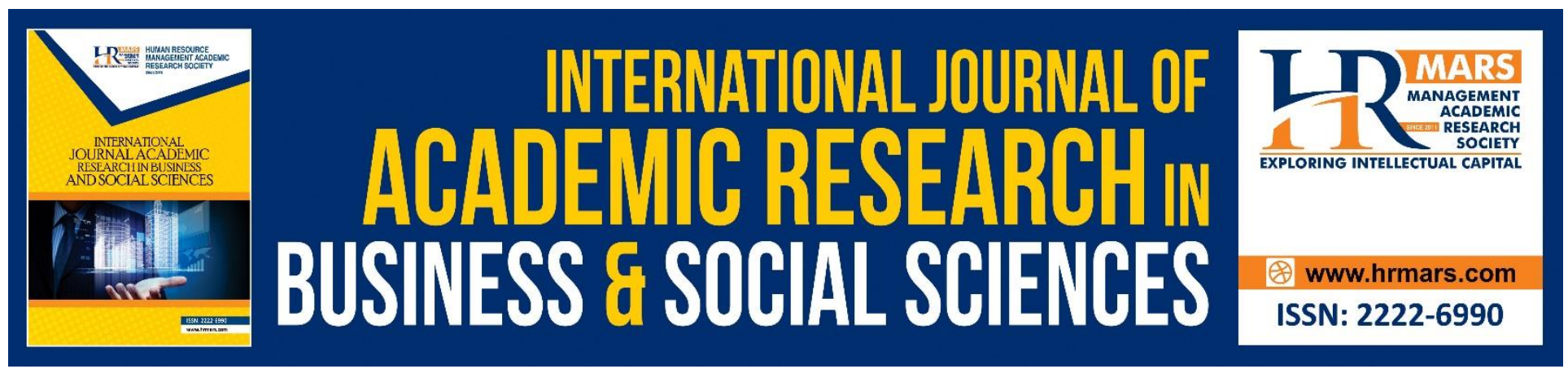

\title{
The Practice of Design and Technology Teachers in Pahang towards Green Technology
}

Saidatul Amira Hamzah, Irdayanti Mat Nashir

To Link this Article: http://dx.doi.org/10.6007/IJARBSS/v9-i3/5790

DOI: $10.6007 /$ IJARBSS/v9-i3/5790

Received: 23 Jan 2019, Revised: 07 Feb 2019, Accepted: 23 Feb 2019

Published Online: 13 March 2019

In-Text Citation: (Hamzah \& Nashir, 2019)

To Cite this Article: Hamzah, S. A., \& Nashir, I. M. (2019). The Practice of Design and Technology Teachers in Pahang Towards Green Technology. International Journal Academic Research Business and Social Sciences, 9(3), 1210-1219.

Copyright: (C) 2019 The Author(s)

Published by Human Resource Management Academic Research Society (www.hrmars.com)

This article is published under the Creative Commons Attribution (CC BY 4.0) license. Anyone may reproduce, distribute, translate and create derivative works of this article (for both commercial and non-commercial purposes), subject to full attribution to the original publication and authors. The full terms of this license may be seen

at: http://creativecommons.org/licences/by/4.0/legalcode

Vol. 9, No. 3, 2019, Pg. $1210-1219$

http://hrmars.com/index.php/pages/detail/IJARBSS

JOURNAL HOMEPAGE

Full Terms \& Conditions of access and use can be found at http://hrmars.com/index.php/pages/detail/publication-ethics 


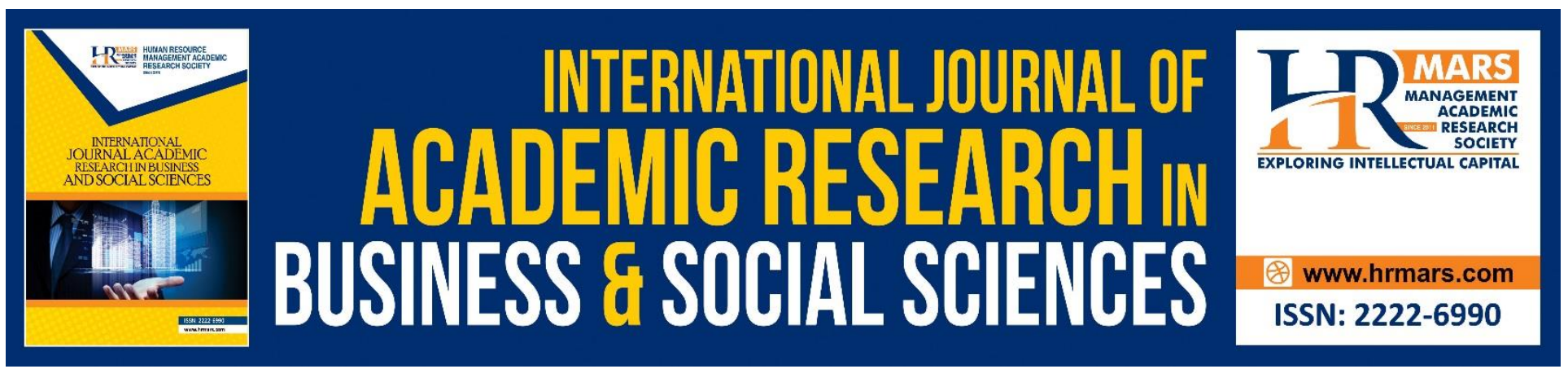

\title{
The Practice of Design and Technology Teachers in Pahang Towards Green Technology
}

\author{
Saidatul Amira Hamzah, Irdayanti Mat Nashir \\ Department Of Engineering Technology, Faculty Of Technical And Vocational, \\ Universiti Pendidikan Sultan Idris, 35900 Tanjong Malim, Perak Darul Ridzuan, Malaysia.
}

\begin{abstract}
Design and Technology subject is the new subject implemented in 2017 to replace Kemahiran Hidup or the Integrated Living Skills subject which had been established over the last 29 years. The purpose of Design and Technology subject were introduced is for the students to practice and apply relevant moral values when designing a more ergonomic and user-friendly product, able to produce a highquality product with cost-effective, and able to create Green Product Designs. In order to produce students that are capable of producing a product with the concept of Green Technology or Green Product Designs, the teachers should first and foremost be competent and fully understand about Green Technology. Therefore, Design and Technology teachers need to adopt green practices or 'Going green' in their everyday life. Thus, this study is conducted with the aims of identifying the practices among Design and Technology teachers in national schools located in Pahang state on Green Technology. This study is carried out by using a quantitative approach in which a questionnaire that consists of 23 items would be distributed to 210 of Design and Technology teachers as a research instrument. Based on the descriptive statistics analysis obtained by the researchers, it is found that the practice of Design and Technology teachers is high towards Green Technology. This matter is proven when the respondents that answered the questionnaire in the practical domain obtained a total mean score of 4.28 and with the standard deviation of 0.419 .
\end{abstract}

Keywords: Teacher, Practice, Green Technology, Design and Technology

\section{Introduction}

Green Technology or better known as environmental technology is a government effort introduced in Malaysia, in order to restore and minimize the negative impact on the environment caused by humans. The negative impact brought by the human is perceived to be of great significance to the country and to the world. Haliza (2010) stated that human activities are one of the major causes of environmental destruction. This is further exacerbated by human behaviour and attitudes towards environmental, in which human lack of concern, attention and responsibility in preserving the environment has brought a negative impact on nature and the quality of human life. Non-stop 
development activities, logging, and deforestation are becoming a major cause of disasters in this world. Uncontrollable rapid development, industrial wastes such as toxic waste, chemical waste, industrial solid waste and municipal solid waste from the industrial activities are not properly managed and disposed of, and even the developers are greedy to make money without considering the adverse effects of their action on the environment.

Therefore, the government which is seriously concerned with the environmental disasters had taken initiative by introducing a policy to lessen and minimize the effects caused by human activities. The policy that is being referred to is the National Green Technology Policy that was introduced in 2009. The implementation of this National Green Technology Policy is seen as one of the effective solutions in tackling the issue of energy and environment at the same time.

However, after almost nine years of the National Green Technology Policy had been established, community awareness regarding Green Technology is still unfavourable and not many people had taken interest regarding this matter. Based on the study presented by Lim (2010), Qayyum (2010) and Muzdalifah (2011), the findings show that Malaysians' knowledge and their level of awareness about the importance of Green Technology has yet to reach a satisfactory standard. Many are still lack of knowledge regarding the concept of Green Technology. In fact, many people still do not understand what the meaning of Green Technology is. In addition, there are certain societies from various ethnics in Malaysia that do not have an understanding about Green Technology (Bokhari, et al. 2014).

In line with the non-stop developments, which demand public awareness on Green Technology, education is seen as the best way to create a generation with the knowledge and high awareness regarding the environment. Environmental education is very important in raising awareness among the younger generation, especially towards the environmental care and sustainability. In the education system, teachers are the key role and are the main support in the effort to create future human capital, which is skilled and talented (Siti Khadijah, 2013). Azizah and Zanaton (2015) stated that in order to deliver effective practice, the practice must first be initiated by the teacher and only then can apply it to the students. In other words, the teachers should first be exercising and implementing all the good practices before it can be effectively delivered and presented to the students.

\section{Literature Reviews}

Green Technology is one of the efforts that had been set in motion to solve environmental issues. Green Technology refers to the development and application of products, equipment, and systems to conserve the environment and natural resources and to minimize or mitigate the negative effects of human activities (KeTTHA, 2017). According to Bokhari, et al. (2014), Green Technology is an approach taken to deal with the issues of environment and economic growth. Rohani (2013) also noted that Green Technology can improve the country's development in terms of the production as it can help to save the costs such as input cost, energy cost, operating cost and maintenance cost. 
She further added that aside from enhancing human health and life, Green Technology can also increase net asset value and generate profits.

Rohani (2013) also stated that Green Technology can address environmental and natural resources destruction issues. This is because Green Technology can replace the use of non-renewable energy sources (Karmilah \& Jamilah, 2014). Non-renewable energy is a source of energy that will eventually run out, cannot be replaced or replenished and will be exhausted in the near future if it is being used non-stop. Petroleum, natural gas, coal, and nuclear energy are examples of nonrenewable energy.

Therefore, the applications of Green Technology are effective as it reduces the impact of global warming and can also mitigate the depletion of energy resources due to human dependency on natural resources. Green Technology applications are seen to have a high potential in enhancing national development (Iskandar, 2015). Hence, the awareness about Green Technology is indispensable from all societies, in which it is important in order to preserve and conserve the environment.

Hasnah et al, (2012) expressed that the awareness of Green Technology can be enhanced through practice factors. Green practices or 'Going Green' can prevent environmental pollution and can help save flora and fauna. Based on the green practice guidelines in "Garis Panduan Amalan Hijau Anggota Kumpulan Melaka Berhad" (2018), it had listed several green practices that can be applied when doing daily tasks at the workplace, namely saving electricity, water-saving, paper-saving, practicing the 3R's, used eco-friendly products, Do and Don'ts in the cafeteria, and the aspects of transportation. On that account, in order to create community awareness regarding the environment through Green Technology, education is an important medium in raising human consciousness. One of the ways to raise awareness of Green Technology through education is to integrate Green Technology into the process of teaching in the classroom.

Design and Technology subject is one of the education that emphasizes in the use of Green Technology. Design and Technology subject is a new subject introduced to the students that replaced the Integrated Living Skills subject, which aims to provide students with knowledge, skills, values, aesthetics, and technology in the design world. Able to produce products that are designed with the concept of green technology and practiced moral values that are relevant when designing a more ergonomic and user-friendly product, and to produce a high-quality product with cost-effective is the purpose of this subject being introduced (DSKP RBT, 2016). It can be concluded that one of the purposes of this D\&T subject being introduced is that to produce a generation with creative and innovative thinking in solving problems regarding the environment by producing products with green features or characteristics.

In achieving the goal across the Secondary School Standard Curriculum for Design and Technology subject, the school needs high-quality teachers with their commitment, in order to provide and implementing the key tasks of educating the future generations. This goal is very difficult 
to achieve if there are no sincere efforts of a dedicated and committed teacher. Teachers who lack knowledge, skills, or commitment in the current environment will have difficulties to produce students who are environmentalists. This means that when teachers want to guide students in exploring the environmental concepts, the teachers must first understand these concepts in advance. This is to say that the teachers should first take the first action by exercising and implementing the practices so, that it can be effectively delivered and presented to the students. Hence, this study was conducted to look at the level of practices on Green Technology among Design and Technology teachers.

\section{Methodology}

In the context of this study, the researchers used a quantitative research method whereby the technique used to collect data is through a designed survey. According to Azhari and Mustapha (2016), surveys are used to measure perceptions or to obtain opinions regarding issues, services or products. The survey method was selected because there were many benefits from it and it was also in line with this study. Among its benefits as what had been pointed by Zaharuzzaman and Azmi (2013), the data can be collected quickly and easily, saves time and expenses, and a large number of respondents can be examined. This quantitative research method involves a descriptive analysis. Descriptive analysis is used to answer the research questions, namely to identify the practice of Design and Technology teachers on Green Technology.

In the selection of study populations, which is related to the practice of Design and Technology teachers on Green Technology, the researchers have chosen a population comprises 457 teachers that teach Design and Technology subject in national schools located in Pahang state. The researchers had collected data, which recorded the total number of Design and Technology teachers in all national schools from the School Management Division-Ministry of Education Malaysia. In order to determine the sample size in this study, the researchers had referred to the table of sample size determination by Krejcie and Morgan (1970). Based on the table, the number of respondents selected to represent the population of this study is 210 people, in which the number of the population chosen is closed to 457.

The instrument used in this study is the questionnaire adapted from the questionnaires used by the previous researchers. The constructed questionnaire consists of two parts, Part A and Part B. Part A comprises four questions, which related to the teacher's demographic information. Whereas, Part B comprises 23 questions that are related to the practice of teachers on Green Technology. For Part $B$, it requires the respondents to choose their answers based on five-level Likert item, namely; 1-Strongly Disagree; 2-Disagree; 3-Neither agree or disagree; 4-Agree; and 5-Strongly Agree. The data were then analysed descriptively by using Statistical Package for The Social Science' (SPSS) software. In terms of the questionnaire reliability in this study, the researchers opted to use the Rasch Measurement Model to test the reliability of the items and individuals by looking at the value of Cronbach's coefficient alpha ( $\alpha$ ). According to Bond \& Fox (2007), the acceptable Cronbach's Alpha $(\alpha)$ value ranges from 0.61 to 1.0 . The reliability value of Cronbach's Alpha is as shown in Table 1 below. 
INTERNATIONAL JOURNAL OF ACADEMIC RESEARCH IN BUSINESS AND SOCIAL SCIENCES

Vol. 9, No. 3, March, 2019, E-ISSN: 222 2-6990 @ 2019 HRMARS

Table 1: The Interpretation of Cronbach's Alpha Score.

\begin{tabular}{cc}
\hline Cronbach's Alpha Score & Reliability \\
\hline $0.9-1.0$ & Very good \\
$0.7-0.8$ & Good and acceptable \\
$0.6-0.7$ & Acceptable \\
$<0.6$ & The items need to be revised \\
$<0.5$ & The items need to be discarded \\
\hline
\end{tabular}

(Source: Bond \& Fox 2007)

Table 2 below shows a summary statistic that measured 210 respondents and a total of 23 items. It can be seen that the individual reliability index is 0.89 , in which, according to Bond \& Fox (2007), the reliability value recorded is good and acceptable. Meanwhile, the items reliability index is 0.98 . Item reliability value is very good (Bond \& Fox, 2007). Hence, the reliability of the Green Technology practice items among Design and Technology teachers is high.

Table 2: Reliability Analysis of Green Technology Practice Instruments.

INPUT: 210 PERSON 23 ITEM REPORTED: 210 PERSON 23 ITEM 5 CATS WINSTEPS 3.73

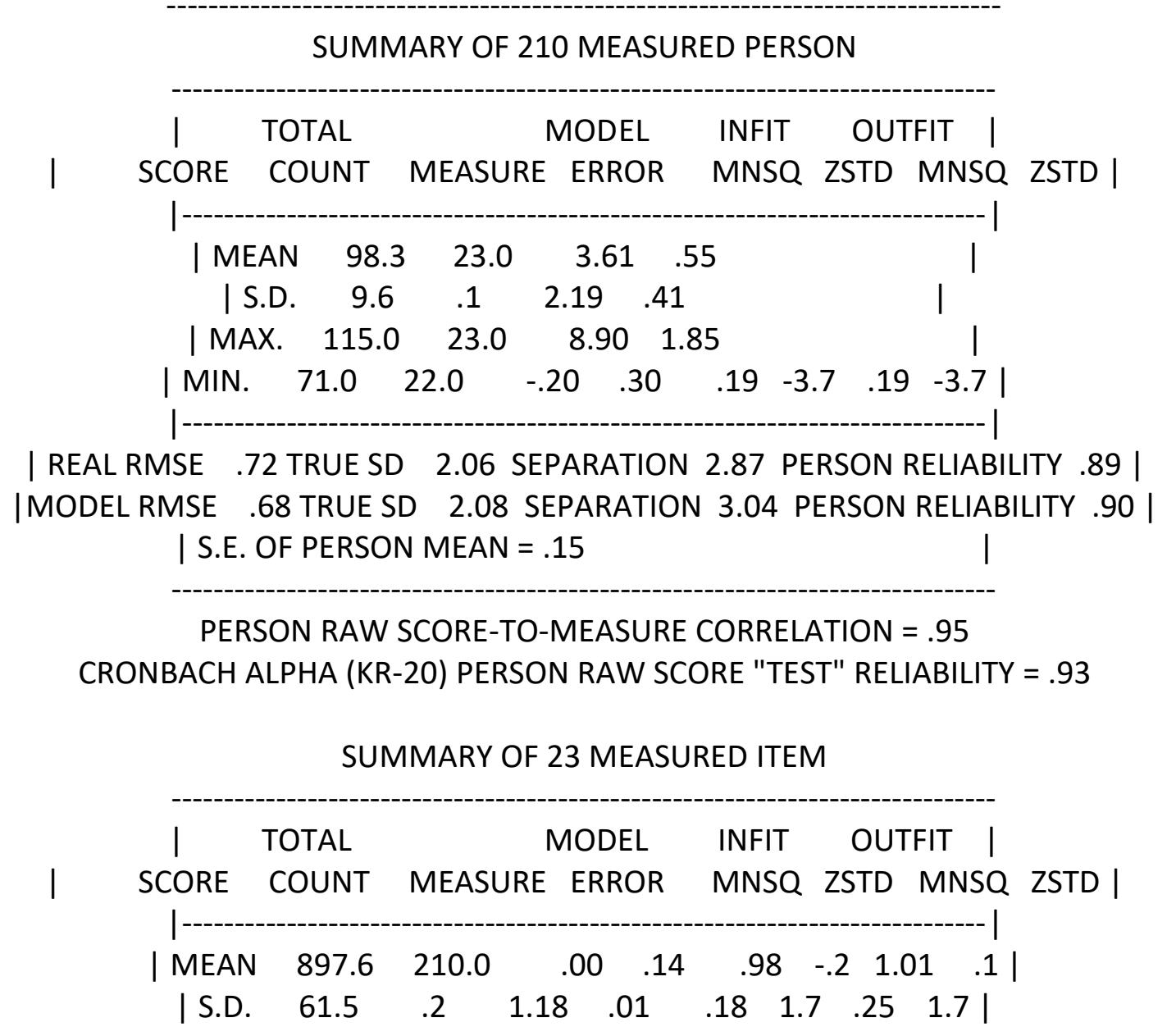


INTERNATIONAL JOURNAL OF ACADEMIC RESEARCH IN BUSINESS AND SOCIAL SCIENCES Vol. 9, No. 3, March, 2019, E-ISSN: 222 2-6990 @ 2019 HRMARS

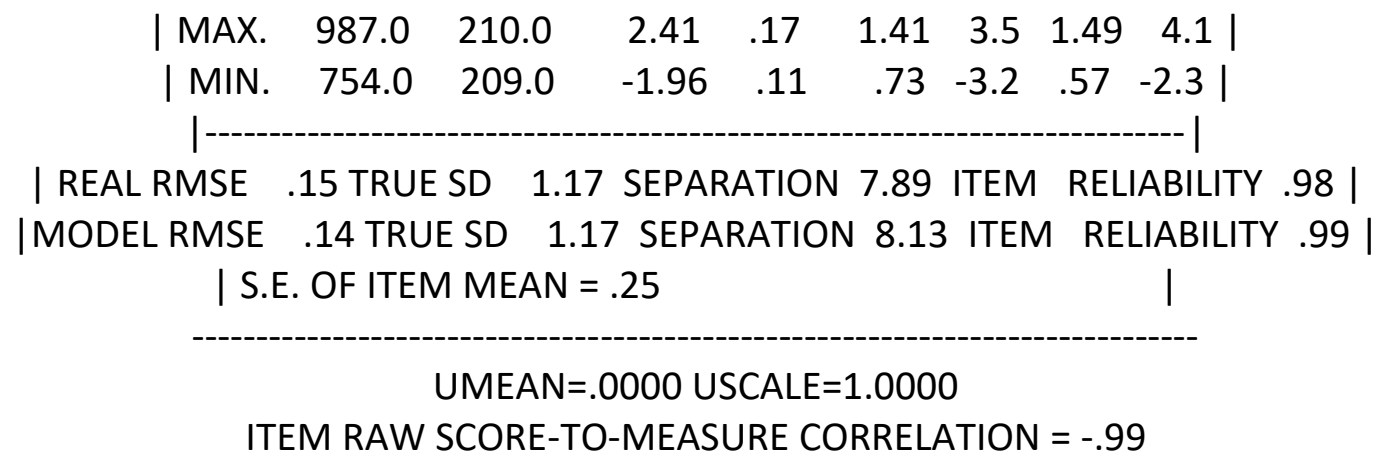

\section{Findings}

This study was conducted among 143 (68.1\%) female teachers and 67 (31.9\%) male teachers who taught Design and Technology subject in national schools, which located in the State of Pahang and with different age groups. The interpretation of mean score by Latip (2006) is used to determine the level of practice among Design and Technology teachers towards Green Technology. As stated by Latip (2006), the score between 4.01 and 5.00 indicates a high level of consent, while the mean score between 3.01 and 4.00 indicates a high-moderate level of agreement. Next, the mean score between 2.01 and 3.00 suggests that the consent is at a low-moderate level. And lastly, the mean score between 1.00 and 2.00 indicates a low level and is in bad condition.

Based on Table 3 as shown below, the descriptive analysis found that the overall mean of Design and Technology teachers' practice is 4.28 and the standard deviation is at a high level. Therefore, it can be concluded that Design and Technology teachers in national schools at Pahang state do practice Green Technology. "I opened the window and the door of the workshop in order to bring the light into the workshop/class." is a statement about teachers' practice of Green Technology, in which it has the highest mean of 4.70 with a standard deviation of 0.459 . Meanwhile, based on Table 3 the statement with the lowest mean is "I brought my own food container when buying food." with a mean of 3.59 and the standard deviation is 0.945 , which is at a high-moderate level.

Table 3: Analysis of Design and Technology Teachers that Practices Green Technology.

\begin{tabular}{|c|l|c|c|c|}
\hline $\begin{array}{c}\text { Item } \\
\text { No. }\end{array}$ & \multicolumn{1}{|c|}{ Statement } & $\begin{array}{c}\text { Mean } \\
\text { Score }\end{array}$ & $\begin{array}{c}\text { Standard } \\
\text { Deviatio } \\
\mathbf{n}\end{array}$ & $\begin{array}{c}\text { Level of } \\
\text { Practices }\end{array}$ \\
\hline 1 & $\begin{array}{l}\text { I make sure all switches are off when leaving } \\
\text { home }\end{array}$ & 4.67 & .471 & High \\
\hline 2 & $\begin{array}{l}\text { I opened the windows and doors of the } \\
\text { workshop in order to bring light into the } \\
\text { workshop/class. }\end{array}$ & 4.70 & .459 & High \\
\hline 3 & $\begin{array}{l}\text { I closed the windows and doors when the air } \\
\text { conditioner is turned on. }\end{array}$ & 4.62 & .534 & High \\
\hline 4 & $\begin{array}{l}\text { I used the stairs to go up/down to another } \\
\text { level. }\end{array}$ & 4.48 & .597 & High \\
\hline
\end{tabular}


INTERNATIONAL JOURNAL OF ACADEMIC RESEARCH IN BUSINESS AND SOCIAL SCIENCES Vol. 9, No. 3, March, 2019, E-ISSN: 222 2-6990 @ 2019 HRMARS

\begin{tabular}{|c|c|c|c|c|}
\hline 5 & $\begin{array}{l}\text { I make sure that the water faucet is tightly } \\
\text { closed. }\end{array}$ & 4.64 & .490 & High \\
\hline 6 & $\begin{array}{l}\text { When I brushed my teeth, I closed the water } \\
\text { faucet. }\end{array}$ & 4.40 & .644 & High \\
\hline 7 & $\begin{array}{l}\text { I do not remove oil, paint, or chemicals in a } \\
\text { sink or toilet. }\end{array}$ & 4.50 & .679 & High \\
\hline 8 & I bought organic products & 4.08 & .701 & High \\
\hline 9 & $\begin{array}{l}\text { I practiced the 3R's (Reduce, Reuse \& } \\
\text { Recycle) }\end{array}$ & 4.23 & .632 & High \\
\hline 10 & $\begin{array}{l}\text { I do not burn household garbage } \\
\text { everywhere. }\end{array}$ & 4.29 & .630 & High \\
\hline 11 & $\begin{array}{l}\text { I watered the trees using water from } \\
\text { rainwater catchment. }\end{array}$ & 3.81 & .833 & $\begin{array}{l}\text { High- } \\
\text { moderat } \\
\text { e }\end{array}$ \\
\hline 12 & I am involved in recycling activities. & 4.04 & .738 & High \\
\hline 13 & $\begin{array}{l}\text { I carried my own bag when shopping (to } \\
\text { reduce plastic consumption). }\end{array}$ & 3.69 & .961 & $\begin{array}{l}\text { High- } \\
\text { moderat } \\
\text { e }\end{array}$ \\
\hline 14 & $\begin{array}{l}\text { I built a model/mock-up from recycled } \\
\text { materials. }\end{array}$ & 4.10 & .702 & High \\
\hline 15 & $\begin{array}{l}\text { I reused the paper, envelope, and file that } \\
\text { has been used. }\end{array}$ & 4.22 & .634 & High \\
\hline 16 & $\begin{array}{l}\text { I practiced the } 3 K^{\prime} \text { 's which is hygiene, health, } \\
\text { and safety in the workshop. }\end{array}$ & 4.35 & .570 & High \\
\hline 17 & $\begin{array}{l}\text { I make sure the safety signage board is } \\
\text { always situated at the right places. }\end{array}$ & 4.38 & .543 & High \\
\hline 18 & $\begin{array}{l}\text { I used the tools and machines according to } \\
\text { the rules and usage instructions provided. }\end{array}$ & 4.43 & .568 & High \\
\hline 19 & $\begin{array}{l}\text { I follow the schedule provided in handling } \\
\text { the equipment and machine maintenance. }\end{array}$ & 4.12 & .664 & High \\
\hline 20 & $\begin{array}{l}\text { I practiced } 5 S^{\prime} \text { 's in the management of the } \\
\text { workshop. }\end{array}$ & 4.25 & .615 & High \\
\hline 21 & $\begin{array}{l}\text { I still walk even if the distance between the } \\
\text { teacher's room and the class/workshop is } \\
\text { far away. }\end{array}$ & 4.45 & .587 & High \\
\hline 22 & $\begin{array}{l}\text { I carry my own water bottle that can be } \\
\text { reused to the school. }\end{array}$ & 4.29 & .645 & High \\
\hline 23 & $\begin{array}{l}\text { I carry my own food container when buying } \\
\text { food. }\end{array}$ & 3.59 & .945 & $\begin{array}{l}\text { High- } \\
\text { moderat } \\
\mathrm{e}\end{array}$ \\
\hline \multicolumn{2}{|r|}{ Total } & 4.28 & 0.419 & High \\
\hline
\end{tabular}




\section{Conclusion}

In conclusion, quantitative research had been conducted to see the daily practices of Design and Technology teachers in the State of Pahang on Green Technology. The results obtained from this quantitative research can provide answers to the questions raised, which is the practices of Design and Technology teachers on Green Technology is high. Based on the findings generated from the analysis of the data collected, it shows that each item that measures the practices of Green Technology can prove that Design and Technology teachers do practices Green Technology, in which almost all items were agreed by the teachers according to the survey conducted. In contrast to the study produced by Zuhair (2015), which centred on the teachers of North Zone Engineering Technology regarding Green Technology practices, where it shows that the practices of Green Technology among teachers of North Zone Engineering Technology are at a moderate level. Similarly, the study conducted by Jamilah et al. (2011) on public regarding environmental practices are also at a low level. Hence, it can be concluded that Design and Technology teachers in national schools located in Pahang state do practices Green Technology that bring about environmental prosperity.

There are several recommendations that can be made to the parties that are responsible for improving the practice of teachers and the community in regards to Green Technology. The teachers should be more serious in exercising their Green Technology practices in daily life, whether at school or at home as they can set an example for the community to follow. Green Technology needs to be valued and understood by the teachers. This is because, as a role model the teachers have the ability to influence the society in educating and cultivating positive attitudes and practices towards Green Technology and ultimately be responsible towards the environment. In addition, the responsible parties, especially the Ministry of Energy, Science, Technology, Environment, and Climate Change also needs to actively play their roles (MESTECC). In order to run a good and well-received Green Technology related programs, the programs should be designed to be an exciting program that can be participated by not only teachers but also from various levels of society. The promoted program should be of interest and relevance. The organizers also need to take into consideration various factors such as time constraints so that people from various levels of society can participate.

\section{References}

Anny, L. K. (2010). Teknologi Hijau: Semua Pihak Perlu Berperanan, Majalah Sains.Com. Jabatan Sains \& Teknologi Untuk Masyarakat: Universiti Kebangsaan Malaysia. https://www.majalahsains.com/teknologi- hijau-semua-pihak-perlu-berperanan/

Bond, T. G, \& Fox, C. M. (2007). Applying the Rasch Model: Fundamental Measurement in the Human Sciences. Mahwah, New Jersey

Haliza, A. R. (2010). Human rights to environment in Malaysia. Health and the Environment Journal 1(1): 59-64.

Hasnah, H., Ishak, I., Yuvaraj, G., \& Suraiya, M. M. (2012). Factors Influencing Loan Approval of SMEs. Paper presented at 14th Malaysian Finance Association Conference 2012. "Emerging Markets and Financial Resilience: Decoupling Growth from Turbulence." Parkroyal Hotel, Penang on 1 - 3 June, pp. 708-729. ISBN: 978-967-394-093-6 
INTERNATIONAL JOURNAL OF ACADEMIC RESEARCH IN BUSINESS AND SOCIAL SCIENCES

Vol. 9, No. 3, March, 2019, E-ISSN: 222 2-6990 @ 2019 HRMARS

Karmilah, A., \& Jamilah, A. (2014). Impak pemerkasaan teknologi hijau terhadap amalan pengamal perhubungan awam hijau di Malaysian Green Technology Corporation (GreenTech Malaysia). AKADEMIKA, 84 (3). pp. 29-39. ISSN 0126-5008

KSSM. (2016). Dokumen Standard Kurikulum dan Pentaksiran Reka Bentuk dan Teknologi tingkatan 2. Bahagian Pendidikan Kurikulum, Kementerian Pendidikan Malaysia

Krejcie, R. V., \& Morgan, D. W. (1970). Determining Sample Size for Research Activities. Educational and Psychological Measurement. 30(3):607-610.

Jamilah, A., Hasrina, M., Hamidah, A. H., \& Juliana, A. W. (2011). Pengetahuan, sikap dan amalan masyarakat Malaysia terhadap isu alam sekitar. Jurnal Akademika, 81(3), 103-115

Latip, M. (2006). Perlaksanaan Kepemimpinan Pengajaran Di Kalangan Pengetua Sekolah Di Negeri Selangor Darul Ehsan. Phd thesis. Universiti Kebangsaan Malaysia.

Mohamad, B. I., Aida, N. A., Syed, N., Zanariah, J., \& Rosli, S. (2014). Hubungan Antara Kefahaman, Kesedaran Dan Amalan Teknologi Hijau Berdasarkan Perspektif Etnik Di Negeri Melaka. Journal of Human Capital Development, 7(2), 2014, 33-46

Mohamed, N. A., \& Ramlee, M. (2016). Pendidikan Teknikal Dan Vokasional: Pendekatan Penyelidikan, Analisis Dan Interpretasi. Universiti Pendidikan Sultan Idris

Mohd, Z. A. (2015). Tahap Kesedaran Teknologi Hijau Dalam Kalangan Guru-Guru Teknologi Kejuruteraan Zon Utara.UTHM

Muhammad, Q. (2010). Antara Masyarakat Hijau Dan Teknologi Hijau https://mqayyum.wordpress.com/2010/07/24/antara-masyarakat-hijau-dan-teknologihijau/

Noor, A. S., \& Zanaton, H. I. (2015). Kesedaran Alam Sekitar Melalui Aplikasi Kendiri Alam Sekitar (KAKAS). Jurnal Personalia Pelajar

Khatijah, S. (2013). Kesediaan bakal guru dpli terhadap mata pelajaran reka cipta untuk mengajar di sekolah menengah: kajian di UTHM. Master's thesis, Universiti Tun Hussein Onn Malaysia

Rohani, J. S. (2013). Kesedaran teknologi hijau dalam kalangan warga Universiti Tun Hussein Onn Malaysia. PHD thesis, UTHM.

Zaharuzzaman \& Kamaru, A. (2013). Gaya Pembelajaran dan Hubungannya dengan Motivasi Pelajar: Satu Kajian Tinjauan di Pusat Pendidikan Andalus Peringkat Menengah di Singapura. Prosiding Seminar Pasca Siswazah Pertama, Fakulti Tamadun Islam, Universiti Teknologi Malaysia. 